\title{
Audit Sistem Informasi Kesiman Kertalangu (SIKEKAL) Menggunakan COBIT 4.1
}

\author{
Made Dwi Mulyawan1, Rukmi Sari Hartati2, Yoga Divayana3 \\ [Submission: 09-09-2020, Accepted: 17-12-2020]
}

\begin{abstract}
Information System of Kesiman Kertalangu (SIKEKAL) is a system implemented in the Kesiman Kertalangu Village as a solution to facilitate the accommodation of population administration services. To measure and evaluate the performance of the system used it is necessary to conduct an audit using the COBIT 4.1 framework, which in this case is focused on measuring the maturity level of the SIKEKAL system based on aspects of the DS (Delivery and Support) domain, especially in the subdomains of DS5, DS10, DS11, and DS13. This evaluation process also aims to provide recommendations for problems found in the system to be able to be improved in achieving the maturity target to be achieved by the Kesiman Kertalangu Village Office.
\end{abstract}

Keywords- COBIT 4.1, Maturity Level, Domain, Information System

Intisari-Sistem Informasi Kesiman Kertalangu (SIKEKAL) merupakan sebuah sistem yang diterapkan pada Desa Kesiman Kertalangu sebagai solusi untuk mempermudah dalam akomodasi proses pelayanan administrasi kependudukan. Untuk mengukur dan mengevaluasi kinerja sistem yang digunakan perlu dilakukan sebuah audit dengan menggunakan framework COBIT 4.1, dimana dalam hal ini difokuskan dalam mengukur maturity level pada sistem SIKEKAL berdasarkan aspek dari domain DS (Delivery and Support) khususnya pada sub domain DS5, DS10, DS11 dan DS13. Proses evaluasi ini juga bertujuan untuk memberikan rekomendasi terhadap permasalahan yang ditemukan pada sistem untuk dapat dilakukan perbaikan dalam mencapai target maturity yang ingin dicapai oleh Kantor Desa Kesiman Kertalangu.

\section{Kata Kunci-COBIT 4.1, Maturity Level, Domain, Sistem Informasi}

\section{PENDAHULUAN}

Kantor Desa Kesiman Kertalangu sebagai pusat pelayanan dan informasi publik mempunyai misi untuk meningkatkan pelayanan publik yang transparan dan efisien. Oleh karena itu Kantor Desa Kesiman Kertalangu membutuhkan suatu fasilitas yang menerapkan teknologi informasi untuk membantu dan mempermudah dalam mengelola dan memberikan pelayanan administrasi kepada warga yang bertempat tinggal di Desa Kesiman Kertalangu. Pemerintah Desa Kesiman Kertalangu

dalam hal ini telah menerapkan aplikasi Sistem Informasi

${ }^{1}$ Mahasiswa, Magister Teknik Elektro Universitas Udayana, Gedung Pascasarjana Universitas Udayana Jl. PB Sudirman Denpasar-Bali, Kode Pos: 80232; (tlp/fax: 0361-239599; e-mail: dwi.mulyawan@student.unud.ac.id)

2,3 Dosen, Magister Teknik Elektro Universitas Udayana, Gedung Pascasarjana Universitas Udayana Jl. PB Sudirman Denpasar-Bali, Kode Pos: 80232; (tlp/fax: 0361-239599; e-mail: ${ }^{2}$ rukmisari@unud.ac.id, 3 yoga@unud.ac.id)
Kesiman Kertalangu (SIKEKAL) untuk mengakomodir seluruh proses pelayanan administrasi di Desa Kesiman Kertalangu. SIKEKAL merupakan sebuah sistem informasi yang dapat mengakomodasi sebagian besar kegiatan administrasi di Kantor Desa Kesiman Kertalangu, mulai dari pencatatan data kependudukan, pencatatan data usaha, pembuatan surat dan pelaporan secara cepat dan akurat. SIKEKAL merupakan salah satu inovasi dalam penerapan teknologi informasi yang bertujuan untuk mempermudah pelayanan administrasi operasional di Kantor Desa Kesiman Kertalangu. SIKEKAL juga dilengkapi dengan statistik untuk melihat jumlah penduduk berdasarkan kategori tertentu dan pelaporan administrasi berdasarkan periode tertentu.

SIKEKAL saat ini telah dijalankan oleh setiap entitas di lingkungan Pemerintah Desa Kesiman Kertalangu sesuai dengan fungsinya, akan tetapi pada saat ini belum dilakukan upaya dalam mengevaluasi kinerja pelaksanaan aplikasi tersebut. Evaluasi kinerja pada sistem informasi ini dilakukan untuk mengetahui sejauh mana SIKEKAL telah dapat dioperasikan secara baik sesuai dengan Standar Operasional Prosedur (SOP) yang berlaku pada instansi tersebut. Dalam proses evaluasi sistem informasi, terdapat framework yang dapat digunakan untuk melakukan evaluasi sistem informasi yaitu COBIT 4.1. Secara umum audit berbasis COBIT 4.1 akan mengukur maturity level atau tingkat kematangan dalam penerapan aplikasi yang didasarkan pada domain-domain yang telah ditetapkan pada kerangka kerja COBIT.

Penelitian ini dilakukan untuk melakukan suatu evaluasi aplikasi SIKEKAL yang digunakan pada Kantor Desa Kesiman Kertalangu dengan menggunakan framework COBIT 4.1 yang berfokus pada domain DS (Deliver and Support) dengan memakai sub domain DS5 (Ensure Systems Security) untuk mengetahui tingkat keamanan sistem, DS10 (Manage Problems) untuk mengetahui tingkat manajemen problem yang terjadi pada sistem, DS11 (Manage Data) untuk mengetahui tingkat dalam manajemen data pada aplikasi dan DS13 (Manage Operations) dalam upaya mengukur tingkat manajemen pengoperasian sistem.

\section{LITERATURE REVIEW}

Penelitian tentang audit sistem informasi menggunakan framework COBIT sudah banyak dilakukan sebelumnya. Pada [1] dilakukan suatu pengukuran tingkat kematangan sistem sertifikasi pemerintah menggunakan framework COBIT 5 yang berfokus pada domain EDM, DSS dan APO, hasil pengukuran kematangan sistem berada pada level 2 (Manage Process). Penelitian [2] dilakukan audit Sistem Informasi Manajemen Keuangan Daerah yang diterapkan pada Pemerintah Daerah Kabupaten Klungkung dengan memakai

p-ISSN:1693 - 2951; e-ISSN: 2503-2372

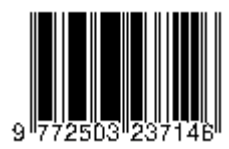


kombinasi COBIT 4.1 dan ITIL V3. Audit yang dilakukan berfokus pada evaluasi sistem dengan menggunakan domain COBIT PO (Plan and Organize). Penelitian [3] dipaparkan mengenai penerapan framework COBIT 4.1 dalam proses evaluasi Sistem Informasi Manajemen Kepegawaian yang digunakan pada Pemerintah Provinsi Bali, evaluasi sistem yang dilakukan berfokus pada domain DS5 dan DS9 untuk mengukur maturity level sistem dalam segi keamanan dan konfigurasi sistem yang digunakan. Penelitian [4] dilakukan pengukuran maturity level sistem pada Sistem Informasi Akademik Universitas Hindu Indonesia dengan memakai framework COBIT 4.1, pengukuran dilakukan berdasarkan seluruh domain COBIT dengan hasil pengukuran tingkat maturity yang dihasilkan sebesar 2.95. Pada [5] dipaparkan mengenai penerapan framework COBIT 4.1 yang difokuskan pada aspek domain Deliver and Support pada perusahaan SaaS StartUp dalam mengukur tingkat kematangan dari sistem yang digunakan pada perusahaan tersebut. Beberapa referensi [6].[7],[8],[9],[10],[11] juga telah melakukan review mengenai framework COBIT terkait penggunaannya dalam melakukan evaluasi terhadap suatu sistem informasi.

\section{METODELOGi PENELITIAN}

\section{A. Tahapan Proses Audit}

Audit Sistem Informasi SIKEKAL dilakukan melalui beberapa tahapan terstruktur sehingga proses penelitian yang dilakukan menjadi lebih terorganisir, sistematis, terkontrol dan terarah. Bagan pada Gambar 2 menggambarkan bagaimana proses penerapan framework COBIT 4.1 dalam mengukur maturity level pada Sistem Informasi Kesiman Kertalangu.

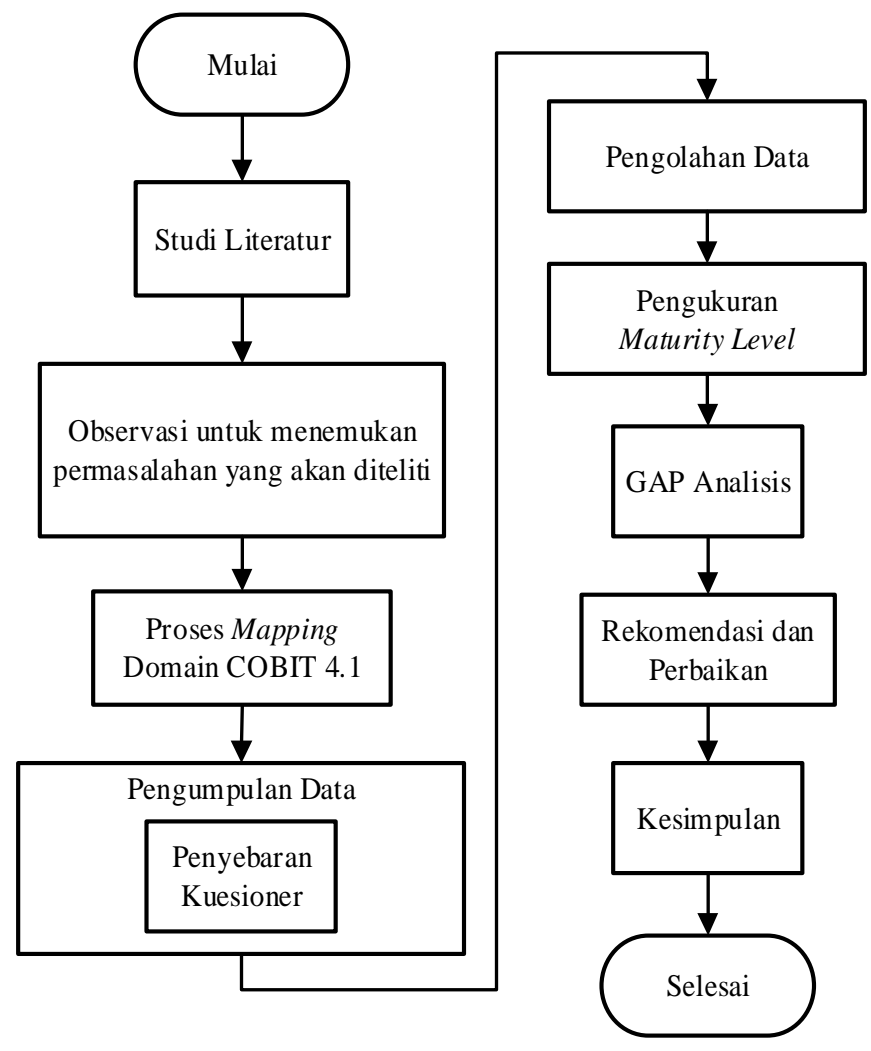

Gambar 1: Tahapan Proses Audit Teknologi Informasi
Penjelasan dari tahapan audit yang akan dilakukan adalah sebagai berikut:

- Studi Literatur merupakan tahap yang dilakukan untuk proses pengumpulan informasi dan referensi yang berhubungan dengan framework COBIT, penelitianpenelitian tentang audit dan beberapa informasi yang berhubungan dengan penelitian audit.

- Identifikasi Masalah, pada tahapan ini dilakukan observasi langsung serta melakukan beberapa wawancara untuk menemukan suatu permasalahan yang terjadi pada sistem informasi yang digunakan oleh instansi yang akan dilakukan proses audit.

- Domain Mapping merupakan proses menetapkan domain COBIT 4.1 yang akan digunakan berdasarkan permasalahan yang telah ditemukan pada tahapan identifikasi masalah melalui wawancara dan pengisian kuisioner.

- Pengumpulan Data dilakukan dengan melakukan penyebaran kuisioner dan wawancara kepada responden yang merupakan pengguna dari sistem informasi yang akan dilakukan proses audit.

- Pengolahan Data akan dilakukan setelah seluruh data yang dibutuhkan telah terkumpul, selanjutnya hasil pengolahan data ini akan dilakukan analisis pada tahapan berikutnya.

- Pengukuran Maturity Level, pada tahapan ini dilakukan pengukuran hasil kuisioner menggunakan Model Maturity COBIT 4.1 untuk dapat mendapatkan hasil maturity level pada aplikasi yang dilakukan proses audit.

- GAP Analisis, merupakan proses analisis kemampuan sistem yang selanjutnya dilakukan proses verifikasi berdasarkan fakta.

- Rekomendasi dan Perbaikan, tahapan ini dilakukan untuk memberikan rekomendasi untuk perbaikan sistem untuk mencapai tingkat kematangan sistem yang diharapkan.

- Kesimpulan merupakan tahapan terakhir dari penelitian ini untuk menyimpulkan berdasarkan hasil yang telah diperoleh.

\section{B. Audit Menggunakan Framework COBIT 4.1}

COBIT (Control Objectives for Information and Related Technology) merupakan suatu framework panduan audit teknologi informasi yang berfungsi menjembatani nilai $G A P$ yang terdapat diantara kebutuhan dan pelaksanaan pemenuhan kebutuhan dalam organisasi maupun instansi [11].

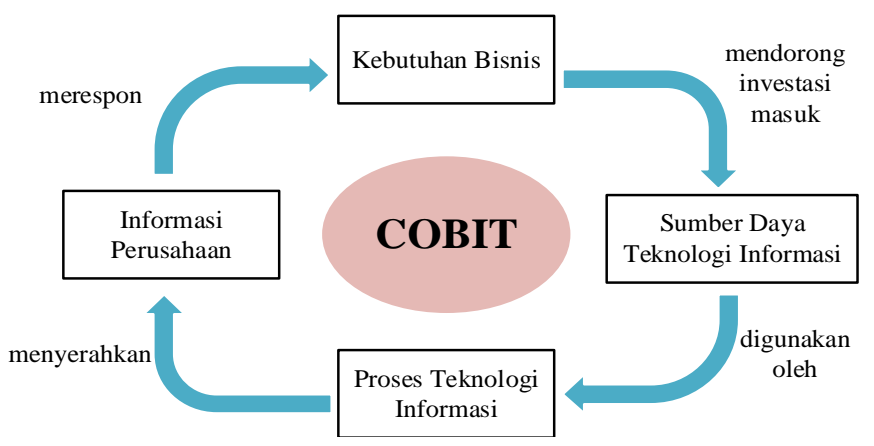

Gambar 2: Prinsip Dasar COBIT 
Prinsip dasar dari framework COBIT ditunjukan pada Gambar 2. Dalam memberikan informasi yang diperlukan perusahaan untuk mencapai tujuannya, perlu dilaukan investasi dalam mengelola dan mengendalikan sumber daya IT dengan menggunakan sekumpulan proses dalam menyediakan layanan yang memberikan informasi perusahaan yang dibutuhkan [12]. Aspek mengelola informasi adalah fokus dari framework COBIT dan membantu memastikan keselarasan dengan standar prosedur dan persyaratan bisnis [13].

COBIT 4.1 memiliki empat domain utama yang dapat digunakan dalam mengidentifikasi proses teknologi informasi yang berjalan. Adapun keempat domain yang digunakan pada framework COBIT 4.1 yaitu:

- Domain Planning and Organization (PO)

- Domain Acquisition and Implementation (AI)

- Domain Delivery and Support (DS)

- Domain Monitoring and Evaluate (ME)

Domain PO berfokus pada taktik dan strategi dalam mengidentifikasi proses teknologi informasi sehingga dapat memberikan kontribusi terbaik untuk mencapai tujuan bisnis. Domain AI memiliki peran untuk mewujudkan strategi dengan melakukan identifikasi dan integrasi solusi teknologi informasi dengan proses bisnis [13],[14]. Domain DS berisi tentang proses implementasi yang diperlukan oleh suatu perusahaan atau instansi yang meliputi layanan sistem berbasis teknologi informasi, pengelolaan keamanan, serta pengelolaan data dan fasilitas operasional. Domain ME berisi tentang penilaian dan pengawasan terhadap kualitas penerapan terhadap peraturan dan persyaratan kontrol proses bisnis [15].

\section{Model Maturity COBIT 4.1}

Model maturity dalam manajemen dan kontrol suatu proses TI berdasarkan pada metode evaluasi organisasi, sehingga maturity level dapat dinilai dari 0 (Non-Existent) hingga 5 (Optimized) yang ditunjukkan pada Tabel 1 [16].

TABEL 1

MATURITY LEVEL PADA COBIT 4.1

\begin{tabular}{|c|c|c|}
\hline Level & Maturity & Keterangan \\
\hline 0 & Non-existent & Tidak adanya proses yang dapat dikenali \\
\hline 1 & $\begin{array}{c}\text { Initial/Ad } \\
\text { Hoc }\end{array}$ & $\begin{array}{c}\text { Adanya bukti bahwa perusahaan telah } \\
\text { mengakui bahwa terdapat masalah dan } \\
\text { perlu ditangani }\end{array}$ \\
\hline 2 & $\begin{array}{c}\text { Repeatable } \\
\text { but Intuitive }\end{array}$ & $\begin{array}{c}\text { Proses telah berkembang ke tahap dimana } \\
\text { prosedur serupa diikuti oleh orang yang } \\
\text { berbeda untuk melakukan tugas atau hal } \\
\text { yang sama. }\end{array}$ \\
\hline 3 & $\begin{array}{c}\text { Defined } \\
\text { Process }\end{array}$ & $\begin{array}{c}\text { Prosedur telah distandarisasi dan } \\
\text { didokumentasikan melalui pelatihan. }\end{array}$ \\
\hline 5 & $\begin{array}{c}\text { Managed } \\
\text { and }\end{array}$ & $\begin{array}{c}\text { Manajemen telah memantau dan mengukur } \\
\text { penerapan prosedur dan mengambil suatu } \\
\text { tindakan dimana jika terjadi suatu proses } \\
\text { yang tidak bekerja secara efektif }\end{array}$ \\
\hline Pearimised & $\begin{array}{c}\text { Proses telah disempurnakan ke tingkat } \\
\text { praktik yang baik, berdasarkan hasil } \\
\text { peningkatan berkelanjutan dan pemodelan } \\
\text { kematangan dengan perusahaan yang lain. }\end{array}$ \\
\hline
\end{tabular}

Pendekatan yang digunakan dalam maturity level berasal dari model maturity yang digunakan Software Engineering
Institute (SEI) didefinisikan untuk kematangan kemampuan pengembangan perangkat lunak [17],[18]. Meskipun konsep pendekatan implementasi COBIT sangat berbeda dari SEI, yang berorientasi pada prinsip-prinsip perangkat lunak. Dalam COBIT, model maturity ini memiliki tujuan untuk mengidentifikasi dimana masalah berada dan menetapkan prioritas untuk perbaikan dari sistem [19],[20].

\section{Proses Pengumpulan Data}

Pengumpulan data pada penelitian ini dilakukan dengan teknik wawancara dan penyebaran daftar pertanyaan atau kuesioner serta observasi atau pengamatan langsung terhadap semua hal yang berhubungan pada proses pengolahan data dalam sistem untuk mengetahui beberapa permasalahan yang ada pada sistem yang digunakan. Permasalahan yang ditemukan pada sistem tersebut selanjutnya dilakukan mapping berdasarkan aspek domain framework COBIT 4.1.

\section{HASIL DAN ANALISIS}

\section{A. Identifikasi Masalah Pada SIKEKAL}

Indentifikasi masalah dilakukan dengan wawancara kepada responden sebagai pengguna dari Sistem Informasi Kesiman Kertalangu (SIKEKAL), selain itu dilakukan observasi langsung untuk mendapatkan dokumentasi sistem dan menemukan permasalahan yang terjadi. Adapun beberapa temuan yang menjadi permasalahan pada sistem adalah sebagai berikut:

- Data kependudukan yang tersimpan pada database yang digunakan tidak ada pembaruan secara otomatis, dalam hal ini belum adanya pembaharuan berkala dan integrasi antara database kependudukan yang dikelola oleh Dinas Kependudukan dan Pencatatan Sipil Kota Denpasar.

- Tidak ada validasi untuk data yang terinput kedalam sistem, sehingga sistem memperbolehkan adanya data ganda atau redudansi data.

- Penanganan saat terjadinya error pada sistem sangat lambat.

- Belum diketahui seberapa besar tingkat kematangan Sistem Informasi Kesiman Kertalangu pada proses manajemen data dan evaluasi kinerja TI.

Sehingga dengan ditemukannya beberapa masalah yang terjadi pada Sistem Informasi Kesiman Kertalangu, diperlukan suatu proses audit untuk mengukur maturity level sistem yang digunakan dan dapat diberikan rekomendasi untuk perbaikan dalam mencapai target yang diinginkan.

\section{B. Pemilihan Responden}

Responden yang digunakan untuk mengumpulkan data yang diperlukan dalam penelitian ini berjumlah 10 yang terdiri dari Kepala Desa, 2 orang Staf IT dan 7 orang user yang dalam hal ini dipilih dari beberapa Kepala Dusun yang bertugas di Desa Kesiman Kertalangu. 
TABEL 2

DAFTAR RESPONDEN

\begin{tabular}{|l|l|}
\hline \multicolumn{1}{|c|}{ Jabatan } & Jumlah \\
\hline Kepala Desa & 1 Orang \\
\hline Staf IT & 2 Orang \\
\hline Kepala Dusun & 7 Orang \\
\hline
\end{tabular}

Maturity Level $=\frac{(0 * y 0)+(1 * y 1)+(2 * y 2)+(3 * y 3)+(4 * y 4)+(5 * y 5)}{z}$

Hasil responden 0-5 merupakan pilihan dari pilihan nilai skala likert, $y(n)$ merupakan nomor proses pada level $n$, dan $z$ merupakan jumlah responden yang digunakan. Sehingga dengan menggunakan Persamaan (1) dapat dihitung maturity

Pemilihan responden pada Tabel 2 dipilih sesuai dengan entitas yang sering terlibat dalam penggunaan aplikasi SIKEKAL dalam melakukan pelayanan administrasi kepada masyarakat di Desa Kesiman Kertalangu, sehingga dapat mengetahui proses kerja dan masalah yang sering terjadi pada system yang digunakan.

\section{Hasil Perhitungan Tingkat Maturity SIKEKAL}

Perhitungan maturity level SIKEKAL dilakukan dengan berdasarkan data yang telah didapatkan melalui pengisian kuesioner yang telah dijawab oleh responden yang dipilih pada tahapan pengumpulan data. Kuesioner ini telah dilakukan proses mapping yang berfokus pada domain COBIT Delivery and Support dengan sub domain DS5, DS10, DS11 dan DS13, proses mapping ini dilakukan berdasarkan temuan masalah yang ada pada aplikasi SIKEKAL.

TABEL 3

HASIL PERHITUNGAN TINGKAT MATURITY APLIKASI SIKEKAL

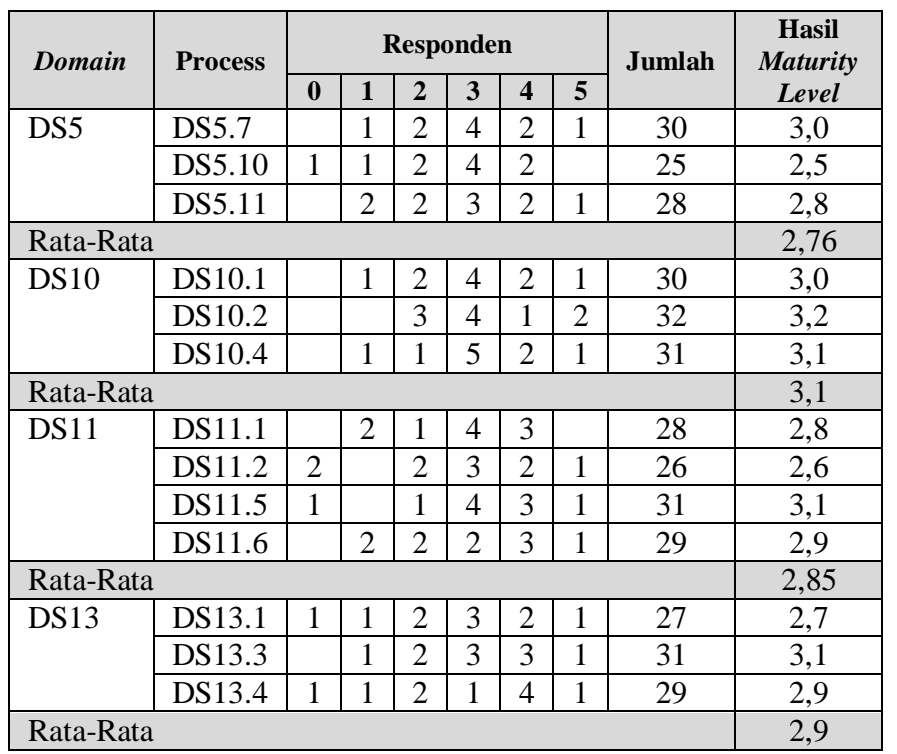

Berdasarkan Tabel 3 menunjukan rata-rata dari pengukuran maturity level sistem SIKEKAL yang berada pada level 2 (Repeatable but Intuitive) pada domain DS5, DS11 dan DS13, hal ini menunjukan bahwa sistem SIKEKAL telah menerapkan prosedur yang berlaku dalam melakukan manajemen keamanan sistem, manajemen data serta manajemen operasi sistem yang digunakan namun masih terdapat beberapa kesalahan yang memungkinkan untuk terjadi pada proses tersebut. Sedangkan pada domain DS10 berada pada level 3 (Defined Process), dengan ini sistem SIKEKAL dalam proses manajemen permasalahan yang terjadi telah dilakukan berdasarkan proses standarisasi dan didokumentasikan sesuai dengan prosedur.

Maturity Level dihitung dengan menggunakan perhitungan skala likert, dengan rumus sebagai berikut:

level berdasarkan data yang telah didapatkan melalui kuesioner.

\section{Analisis GAP}

Berdasarkan hasil perhitungan maturity level pada sistem SIKEKAL, proses selanjutnya akan dilakukan suatu analisis $G A P$ yang bertujuan untuk mengetahui proses-proses yang dapat dilakukan dalam mencapai maturity level yang diharapkan. Proses pengukuran nilai GAP didapatkan dengan menggunakan Persamaan (2) sebagai berikut:

Hasil GAP $=\sum$ Target Level $-\sum$ Level Saat ini

Dengan menggunakan Persamaan (2), maka didapatkan nilai GAP dari masing-masing maturity level pada setiap sub domain yang digunakan sebagai berikut:

TABEL 4

NILAI GAP

\begin{tabular}{|c|c|c|c|}
\hline Sub Domain & $\begin{array}{c}\text { Target } \\
\text { Level }\end{array}$ & Level Saat Ini & GAP \\
\hline DS5 & 4 & 2,76 & 1,24 \\
\hline DS10 & 4 & 3,1 & 0,9 \\
\hline DS11 & 4 & 2,85 & 1,15 \\
\hline DS13 & 4 & 2,9 & 1,1 \\
\hline
\end{tabular}

Target maturity level yang ingin dicapai oleh Kantor Desa Kesiman Kertalangu adalah level 4 (Managed and Measureable), berdasarkan proses analisis nilai GAP pada Tabel 4 menunjukan bahwa level sistem saat ini berada 1 tingkat dengan level yang ingin dicapai oleh organisasi tersebut. Sehingga memerlukan waktu yang cukup untuk melakukan perbaikan pada sistem dalam mencapai level yang diinginkan.

\section{Representasi Maturity Level}

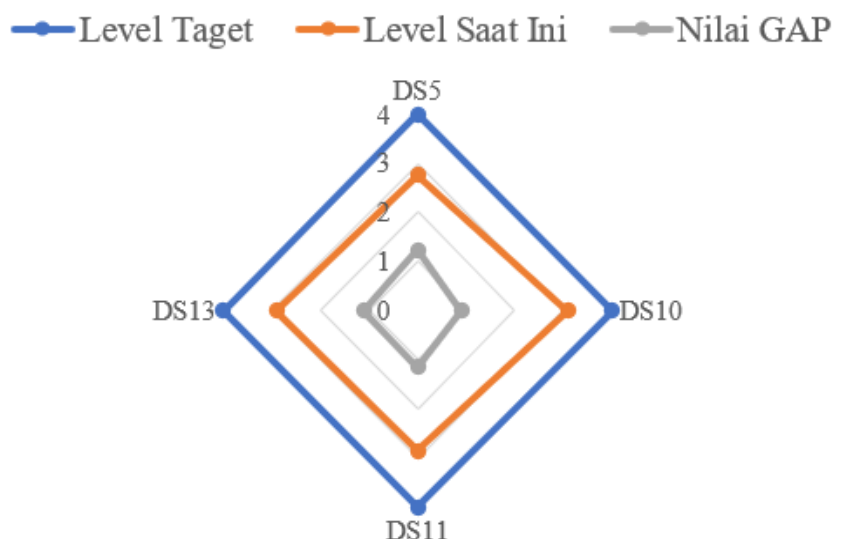

Gambar 3: Representasi Nilai GAP terhadap Maturity Level Aplikasi SIKEKAL

Gambar 3 merupakan tampilan grafik analisis GAP yang merepresentasikan maturity level sistem saat ini dengan tingkatan level yang ingin dicapai oleh instansi. Sehingga 
Majalah Ilmiah Teknologi Elektro, Vol. 19, No. 2, Juli - Desember 2020

DOI: https://doi.org/10.24843/MITE.2020.v19i02.P03

dapat diberikan rekomendasi dan dilakukan perbaikan untuk meminimalkan nilai GAP untuk mencapai suatu target maturity level yang diharapkan pada sistem SIKEKAL.

\section{E. Rekomendasi}

Rekomendasi diberikan pada setiap proses sub domain. Rekomendasi berikut harus dipenuhi secara berurutan untuk meminimalkan nilai GAP terhadap target maturity level yang diinginkan.

- Untuk DS5 dalam memastikan keamanan sistem dari segi pengguna perlu ditambahkan sebuah captcha dalam proses login serta meningkatkan proses keamanan dari sistem cloud sebagai tempat penyimpanan data organisasi.

- Untuk DS10 dalam manajemen permasalahan perlu dilakukan pengecekan terhadap seluruh proses bisnis yang telah diterapkan pada sistem yang digunakan.

- Untuk DS11 dalam manajemen data perlu dilakukan backup data secara berkala dan melakukan integrasi database kependudukan yang dapat diperbarui setiap tahunnya.

- Untuk DS13 dalam manajemen operasi sistem perlu dilakukan pemeliharaan sistem secara berkala untuk meminimalisir terjadinya error yang berdampak pada kinerja sistem.

\section{Kesimpulan}

Berdasarkan hasil dan analisa yang dilakukan pada proses audit sistem SIKEKAL menggunakan COBIT 4.1, dapat disimpulkan bahwa sistem yang digunakan pada Kantor Desa Kesiman Kertalangu berada pada tingkat maturity level 2 (Repeatable but Intuitive) pada proses domain DS5, DS11 dan DS13 serta level 3 (Defined Process) pada proses domain DS10. Proses perbaikan untuk sistem SIKEKAL ditekankan pada keamanan sistem, manajemen data, dan pemeliharaan sistem secara berkala untuk dapat mencapai level target yang ingin dicapai. Hal ini disebabkan karena pada hasil proses audit yang telah dilakukan pada domain DS5 (Ensure System Security) menghasilkan nilai GAP yang paling tinggi yaitu sebesar 1.24, sehingga untuk hal tersebut direkomendasikan agar sistem SIKEKAL dilengkapi dengan captcha pada proses login untuk dapat meningkatkan keamanan sistem dari segi data pengguna dan keamanan pada sistem cloud sebagai tempat penyimpanan data organisasi. Sedangkan pada domain DS11 dan DS13 memiliki nilai GAP sebesar 1.1, sehingga dalam hal ini pada domain DS11 (Manage Data) dalam proses manajemen data direkomendasikan untuk melakukan update data secara berkala agar data yang terdapat pada database sistem SIKEKAL dapat diperbaharui setiap tahunnya. Sedangkan untuk DS13 (Manage Operations) dalam manajemen operasi sistem perlu dilakukan pemeliharaan secara berkala untuk meminimalisir terjadinya error yang berdampak pada kinerja sistem.

\section{UCAPAN TERIMA KASIH}

Ucapan Terima Kasih diucapkan untuk seluruh staf Kantor Desa Kesiman Kertalangu yang telah memberikan kesempatan

Made Dwi Mulyawan: Audit Sistem Informasi Kesiman ...

waktu dan tempat untuk melakukan penelitian pada Sistem Informasi Kesiman Kertalangu (SIKEKAL) yang digunakan.

\section{REFERENSI}

[1] Adriani, N. L. et al. (2018) "Audit of Certification System Governance', International Journal of Engineering and Emerging Technology”, 3(2), pp. 13-17.

[2] Jaya, P. A. P., Widyantara, I. M. O. and Linawati (2017) "Audit Penerapan Aplikasi Sistem Keuangan Pemerintah Daerah Kabupaten Klungkung Menggunakan COBIT Domain PO dan ITIL", Majalah Ilmiah Tekologi Elektro, 16(1), pp. 53-60.

[3] Laksmidewi, A., Linawati, L. and I.M.O, W. (2017) "Evaluasi Sistem Informasi Manajemen Kepegawaian dengan DS5 dan DS9 COBIT 4.1 Studi Kasus : Pemprov Bali”, Majalah Ilmiah Teknologi Elektro, 17(1), p. 25. doi: 10.24843/mite.2018.v17i01.p04.

[4] I Kadek, N. adi J., Widyantara, I. M. O. and Hartati, R. S. (2019) "Audit Manajemen Sumber Daya dan Pengukuran Performa Sistem Informasi Akademik Universitas Hindu Indonesia Menggunakan Framework Cobit 4.1", Majalah Ilmiah Teknologi Elektro, 18(1), p. 35. doi: 10.24843/mite.2019.v18i01.p05.

[5] Anshory, B. J. et al. (2018) "Information System Audit in SaaS StartUp Company using COBIT 4.1 Focus on Deliver and Support Domain", 2018 International Conference on Orange Technologies, ICOT 2018. IEEE, pp. 1-7. doi: 10.1109/ICOT.2018.8705886.

[6] Mulgund, P., Pahwa, P., \& Chaudhari, G. (2019). "Governance and Controls Using COBIT: A Systematic Literature Review. International Journal of Risk and Contingency Management (IJRCM)", 8(4), 66-90. doi:10.4018/IJRCM.2019100104.

[7] Ramakrishnan, M. et al. (2018) "IT service management knowledge ecosystem - Literature review and a conceptual model", ACIS 2018 29th Australasian Conference on Information Systems, pp. 1-8. doi: 10.5130/acis2018.bu.

[8] Fuada, S. (2019) "Incident management of information technology in the indonesia higher education based on COBIT framework: A review", EAI Endorsed Transactions on Energy Web, 19(22), pp. 1-9. doi: 10.4108/eai.13-7-2018.156387.

[9] Putra, I. B. A. E. M., Hartati, R. S. and Divayana, Y. (2020) 'Audit Sistem Informasi E-Kinerja Dinas Kependudukan Dan Pencatatan Sipil Kota Denpasar', Majalah Ilmiah Teknologi Elektro, 19(1), p. 107. doi: 10.24843/mite.2020.v19i01.p16.Prabowo, F. T.,

[10] Wirastuti, N. D. and Kumara, I. N. S. (2017) 'Evaluasi Layanan Broadband Campus Dengan Menggunakan Framework Cobit 4.1', Majalah Ilmiah Teknologi Elektro, 16(2), p. 25. doi: 10.24843/mite.2017.v16i02p06.

[11] Nugraha, A. A., Linawati, L. and Sastra, N. P. (2017) 'Framework Pengelolaan Infrastruktur TIK di Pemerintah Kabupaten Badung', Majalah Ilmiah Teknologi Elektro, 17(1), p. $10 . \quad$ doi: 10.24843/mite.2018.v17i01.p02.

[12] Kumbara, C. R., Linawati, L. and Widyantara, I. M. O. (2017) 'Audit Infrastruktur Aplikasi Pelayanan Publik Pemerintah Kota Denpasar', Majalah Ilmiah Teknologi Elektro, 16(2), p. $78 . \quad$ doi: 10.24843/mite.2017.v16i02p14.

[13] Pawan, E., Utami, E. and Nasiri, A. (2019) 'Mengukur Tingkat Kematangan Tata Kelola Sistem Informasi Akademik Menggunakan COBIT 4.1 dan Balanced Scorecard', Creative Information Technology Journal, 5(2), p. 127. doi: 10.24076/citec.2018v5i2.180.

[14] Nugroho, H. and Gumilang, S. F. S. (2020) 'Recommendations for Improving Data Management Process in Government of Bandung Regency using COBIT 4.1 Framework', ACM International Conference Proceeding Series, pp. 57-61. doi: 10.1145/3384544.3384588.

[15] Debrilla Ivanadya Pang, Suprapto, A. D. H. (2019) 'Implementasi Perancangan Tata Kelola Teknologi Informasi menggunakan Kerangka Kerja Cobit 4.1 pada Bidang Pengelolaan Teknologi Informasi dan Komunikasi (TIK) Diskominfo Kota Madiun', Jurnal Pengembangan Teknologi Informasi dan Ilmu Komputer, 3(5), pp. 4525-4534.

[16] N. Prasetyawan, Endroyono and S. M. S. Nugroho. (2019) "Maturity Level Analysis of Governance and Integration IT of Simkeuda in Pamekasan Regency Using COBIT 4.1" 2019 International Seminar on Intelligent Technology and Its Applications (ISITIA), Surabaya, Indonesia, pp. 222-227, doi: 10.1109/ISITIA.2019.8937230.

[17] S. Kosasi, Vedyanto and I. Dewa Ayu Eka Yuliani. (2020) "Accelerating and Optimizing Digital Businesses through IT

p-ISSN:1693 - 2951; e-ISSN: 2503-2372 
Governance" 2020 International Seminar on Application for Technology of Information and Communication (iSemantic), Semarang, Indonesia, pp. 98-103, doi: 10.1109/iSemantic50169.2020.9234233.

[18] B. J. Anshory, S. Sfenrianto, E. R. Kaburuan, E. Peranginangin and Q. Fadhila. (2018), "Information System Audit in SaaS Start-Up Company using COBIT 4.1 Focus on Deliver and Support Domain" 2018 International Conference on Orange Technologies (ICOT), Nusa Dua, BALI, Indonesia, pp. 1-7, doi: 10.1109/ICOT.2018.8705886.
[19] J. S. Suroso, Sridhatu, Shanlunt, J. J. Halim and K. B. S. Turnip. (2018), "Information System Audit Using Framework Cobit 4.1 on PT Klikfix Asia International," 2018 International Conference on Information Management and Technology (ICIMTech), Jakarta, pp. 261-266, doi: 10.1109/ICIMTech.2018.8528163.

[20] H. A. Pradana et al. (2019), "Audit of Provincial Library Information System based on COBIT 4.1" 2019 1st International Conference on Cybernetics and Intelligent System (ICORIS), Denpasar, Bali, Indonesia, pp. 18-22, doi: 10.1109/ICORIS.2019.8874921. 